\title{
Vibration Energy Harvesting on Vehicle Suspension Using Rotary and Linear Electromagnetic Generator
}

\author{
Arif Indro Sultoni ${ }^{1}$, I Nyoman Sutantra ${ }^{2}$, and Agus Sigit Pramono ${ }^{2}$
}

\begin{abstract}
In this paper, we discuss comparation of vehicle vibration energy harvesting between rotary and linear electromagnetic generator. We construct the two model of energy harvester mechanism and then analyze both of energy absorbtion and vehicle comfortability. Furthermore, we analyze both of energy absorbtion and vehicle comfortability. Vehicle is modeled as quarter car. Rotarty generator harvests $2.5 \times 10^{-4}$ Watt. The other hand, linear generator has viscous characteristic and capable to generates 90 Watts with 12 Volt power supply for $0.03 \mathrm{~m}$ amplitude of bumpy road input. Linear generator reduces oscillation with $1.2 \mathrm{sec}$ settling time. It is more comfort than the angular which has $\mathbf{3}$ sec in settling time. With unnevenees road input, mean power of this generator is 64 Watt.
\end{abstract}

Keywords - Vehicle vibration harvesting energy, rotary electromagnetic generator, linear electromagnetic generator

Abstrak - Pada makalah ini, dibahas penggunaan generator elektromagnetik tipe rotary dan linear untuk suspensi penangkap energi vibrasi yang terjadi pada kedaraan. Kedua model akan dikomparasikan terhadap faktor kemampuan penyerapan energi dan kenyamanannya. Suspensi dengan generator tipe rotary hanya mampu menghasilkan daya $2,5 \times 10^{-4}$ Watt, sedangkan tipe linear mampu menghasilkan daya 90 watt dengan sumber 12 Volt untuk input jalan berupa bump dengan amplitudo 0,03 m. Penggunaan generator linear selain mempunyai sifat damping viscous, mampu meningkatkan kenyamanan dengan kemampuan meredam osilasi pada saat 1,2 detik dibandingkan tipe linear dengan waktu settling selama 3 detik. Dengan input jalan yang tidak rata, generator ini dapat menghasilkan daya rata-rata sebesar 64 Watt.

Kata Kunci-Penangkapan energi vibrasi pada kendaraan, generator elektromagnetik berotasi, generator elektromagnetik linier

\section{INTRODUCTION}

I n recent years, research has been carried out to reduce the fuel consumption of vehicle to protect environment. In automobile, much of energy can be recovered especially vibration energy at suspension system. Developments achieved in permanent magnet materials, microelectronic systems enable the possibility of actual implementation of electromagnetic mechanism to recover energy and improve the performance of vehicle suspension systems. An electromagnetic Energy harvester for suspension has been characterized and analyzed [1]. Reference [2], introduce modeling and analysis regenerative shock absorber using ANSYS. Research on electromagnetic vibration energy recovery model were investigated by [3], A micro electromagnetic generator can deliver $30 \%$ of power from environment to useful electrical power. Harvesting energy form cantilever beam vibration was modeled and verified by experiment in two interesting point, maximizing harvested energy and maximize efficiency [4]. The employing of recovered energy from vibration to control the vibration itself is investigated by [5]. Reference [6], purpose Neuro-fuzzy Controller for actuate hydraulic valve using electromagnetic energy recovery for full car model. Performance of suspension for road and ride holding were presented by [7]. Electromagnetic hybrid

${ }^{1}$ Arif Indro Sultoni is Doctorate Student of Department of Mechanical Engineering, FTI, Institut Teknologi Sepuluh Nopember, Surabaya, 60111, Indonesia. E-mail: arif.sultoni10@mhs.me.its.ac.id.

${ }^{2}$ I Nyoman Sutantra and Agus Sigit Pramono are with Department of Mechanical Engineering, FTI, Institut Teknologi Sepuluh Nopember, Surabaya, 60111, Indonesia. E-mail: tantra@me.its.ac.id, pramono@me.its.ac.id. damper is presented by [8], passive damper and semi/active electromagnetic hybridize to get control effort when work as active and become energy harvester when work as semi active.

In this paper, rotary and linear electromagnetic generator has been compared and analyzed for Multi Purpose Vehicle to produce suspension performance and recover its vibration energy. In this case, rotary or linear electromagnetic generator will operate as energy recovery damper.

\section{A. Electromagnetic Generator}

Electro-magnetism has been used to generate electricity since 1930's not long after Faraday's fundamental breakthrough in electromagnet induction. When an electric conductor moved through a magnetic field, a potential difference is induced between ends of conductor. The electromotive force induced in circuit is proportional to time rate of change of magnetic flux linkage of the circuit, expressed as:

$V=-\frac{d \varphi}{d t}$

Where $\mathrm{V}$ is regenerated voltage and $\varphi$ is flux linkage. In most of the application, the circuit consists of coil of wire with multiple turns and the magnet field created with permanent magnets, so the voltage induced is given by:

$V=-N \frac{d \varphi}{d t}$

where $\mathrm{N}$ is number of coil.

Flux linkage for multiple coil evaluated as the sum of the linkage individual flux,

$\varphi=\sum_{i=1}^{N} \int_{A i} B d A$

Where $B$ is magnetic flux densities over the area of $i^{\text {th }}$ turn. To extract power form generator the coil terminal 
must be connected to a load resistance allowing a current to flow in the coil. Interaction between the field caused by induced current to field form the magnet give rise to a force which opposes the motion and is proportional to the current and the velocity.

$$
F_{e m}=D_{e m} \frac{d x}{d t}
$$

Maximizing the power in the form of electrical energy involve the maximization of electromagnetic damping $\mathrm{D}_{\mathrm{em}}$. The instantaneous power extracted as written as:

$P_{e m}=\frac{F_{e m} d x(t)}{d(t)}$

where $\mathrm{F}_{\mathrm{em}}$ is electromagnetic force.

\section{B. Vehicle Comfort and Handling}

The quality referred to as ride comfort is affected by a variety of factors, including high frequency vibrations, body booming, body roll and pitch, as well as the vertical spring action normally associated with a smooth ride. If the vehicle is noisy, if it rolls excessively in turns, or lurches and pitches during acceleration and braking, or if the body produces a booming resonance, occupants will experience an uncomfortable ride. The ride quality is normally associated with the vehicles relatively low frequency compression and rebound movements as a response to bumps in the road. Following a bump, the un-damped suspension (without shock absorbers) of a vehicle will experience a series of oscillations that will cycle according to the natural frequency of the system. Ride is perceived as most comfortable when the natural frequency is in the range of about $1 \mathrm{~Hz}$ to $1.5 \mathrm{~Hz}$. When the frequency approaches $2 \mathrm{~Hz}$, occupants perceive the ride as harsh. As ISO standard [9], Root Mean Square (RMS) of acceleration is under $0.315 \mathrm{~m} / \mathrm{s}^{2}$. Global signal statistics used to summarize the acceleration time histories include the Root Mean Square (RMS) value defined as:

$R M S(a)=\sqrt{\frac{1}{T}} \int_{0}^{T} a^{2}(t) d t$

Shock absorber damping is also affecting vehicle handling. Compression damping is the damping that a shock absorber provides asit is being compressed, for instance when driving over a bump on the road. If the compression damping is too low, the wheel will lose contact with the road and control over the car is lost. If the compression damping is too high, the road unevenness is transmitted directly through the chassis of the car, which results in a very harsh ride. Rebound damping is the damping that a shock absorber provides as it returns from its compressed state to its equilibrium state. A low rebound damping leads to a very soft ride. A high rebound damping prevents the wheel from returning to its equilibrium state after a bump, which causes it too loose contact with the road.

There is trade off between vehicle comfort and handling represented by Figure 1.

\section{Vehicle Dampers}

Automotive dampers commonly known as shock absorbers are used in vehicle suspension systems to isolate the vehicle chassis from unwanted vibrations due to the road disturbances, and to provide good roadhandling.

The concept of linear damper that generates force proportional to its endings relative velocity is widely used and studied in vibration analysis. Dampers have been developed over the history of automotive technology from simple friction dampers to modern telescopic ones.

Hydraulic damper is commonly used which absorbers suppress vehicle frame vibration by a piston moving through oil. Holes in the piston are covered by valves, which resist the flow of the oil through the holes in a controlled manner to produce the damping effect. It is convert the mechanical energy of the vibration into heat energy, so this mechanical energy is dissipated.

Using electromagnetic dampers (composed of electromechanical elements), the kinetic energy of vehicle body vibration can be regenerated as useful electrical energy.

\section{METHOD AND DESIGN}

At the first the paremeters of vehicle was determined. Vehicle is modeled and analyzed quarter car. At the second we design rotary and linear electromagnetic energy harvester. Model is represented as state space equation. All of model is simulated and compared due to comfort by analizing vibration transferred to passanger and amount of energy absorbtion by analizing power output of generator.

\section{A. Rotary Electromagnetic Suspension Generator}

Vibration harvesting energy with rotary electromagnetic suspension is shown by Figure 2 [10].

Model dynamic is reperesented by Free Body Diagram (FBD) Figure 3.

The dynamic equation at sprung mass is given as

$$
\begin{aligned}
& F_{d V E H}=-m_{s} \ddot{z}_{s}+F_{s s}+F_{d s} \\
& F_{d V E H}=-m_{s} \ddot{z}_{s}+k_{s}\left(z_{s}-z_{u s}\right)+c_{s}\left(\dot{z}_{s}-\dot{z}_{u s}\right) \\
& \text { In the un-sprung mass is: } \\
& F_{d V E H}=m_{u s} \ddot{z}_{u s}-F_{s s}-F_{d s}+F_{k w} \\
& F_{d V E H}=-m_{u s} \ddot{z}_{u s}-k_{s}\left(z_{s}-z_{u s}\right)-c_{s}\left(\dot{z}_{s}-\dot{z}_{u s}\right)+ \\
& \quad+k_{w}\left(z_{u s}-z_{r}\right)
\end{aligned}
$$

Where: $m_{\mathrm{s}}$ is sprung mass, $\mathrm{m}_{\mathrm{us}}$ is un-sprung mass, $\mathrm{m}_{\mathrm{s}}$ is sprung mass, $k_{s}$ is suspension stiffness, $c_{s}$ is suspension damping, $k_{\mathrm{w}}$ is tire stiffness, $\mathrm{z}_{\mathrm{s}}$ is sprung mass level, $\mathrm{z}_{\mathrm{us}}$ is un-sprung mass level and $z_{r}$ is road profile as a system input.

Figure 4 shows Free Body Diagram of the rotary electromagnetic harvester. Dynamic model is follow Equation 11 and 12.

$F_{d V E H}=-b_{1} \dot{\theta}_{1}-k_{1} \theta_{1}+F_{c} r_{1}-J_{1} \ddot{\theta}_{1}$

$F_{c} r_{2 a}-b_{2} \dot{\theta}_{2}-k_{2} \theta_{2}-J_{2} \ddot{\theta}_{2}=0$

where: $b_{1}$ is damping of gear rack, $k_{1}$ is stiffness of gear rack, $F_{c}$ is tangential force, $J_{1}$ is Inertia of gear rack, $\theta_{1}$ is angular displacement of gear rack, $\theta_{2}$ is angular displacement of electromagnetic harvester, $b_{2}$ is damping of electromagnetic harvester, $\mathrm{k}_{1}$ is stiffness of electromagnetic harvester, $\mathrm{J}_{2}$ is Inertia of gear rack. From Equation 7 until 12 we can arrange into state space form as Equation 13 :

Regenerated energy is represented by Equation 14 .

$P=c_{e m} \omega^{2}$

where $c_{e m}=2 N B l r_{c} \cos \theta$ with $\mathrm{N}$ is number of turn electromagnetic turn wire, $\mathrm{B}$ is magnetic flux density, $\mathrm{l}$ is length of electromagnet coil and $r_{e}$ is diameter of rotary. 


$$
\begin{aligned}
& {\left[\begin{array}{c}
\dot{z}_{s} \\
\ddot{z}_{s} \\
\dot{z}_{u s} \\
\ddot{z}_{u s} \\
\dot{\theta}_{1} \\
\ddot{\theta}_{1} \\
\dot{\theta}_{2} \\
\ddot{\theta}_{2}
\end{array}\right]=\left[\begin{array}{cccccccc}
0 & 1 & 0 & 0 & 0 & 0 & 0 & 0 \\
\frac{k_{s}}{m_{s}} & \frac{c_{s}}{m_{s}} & \frac{-k_{s}}{m_{s}} & \frac{-c_{s}}{m_{s}} & \frac{b_{1}}{m_{s}} & \frac{k_{1}}{m_{s}} & 0 & 0 \\
0 & 0 & 0 & 1 & 0 & 0 & 0 & 0 \\
\frac{-k_{s}}{m_{u s}} & \frac{-c_{s}}{m_{u s}} & \frac{k_{s}}{m_{u s}} & \frac{c_{s}}{m_{u s}} & \frac{-b_{1}}{m_{u s}} & \frac{-k_{1}}{m_{u s}} & 0 & 0 \\
0 & 0 & 0 & 0 & 0 & 1 & 0 & 0 \\
0 & 0 & 0 & 0 & \frac{k_{1}}{J_{2} \frac{r_{1}}{r_{2}}-J_{1}} & \frac{b_{1}}{J_{2} \frac{r_{1}}{r_{2}}-J_{1}} & \frac{-k_{2}}{J_{2} \frac{r_{1}}{r_{2}}-J_{1}} & \frac{-b_{2}}{J_{2} \frac{r_{1}}{r_{2}}-J_{1}} \\
0 & 0 & 0 & 0 & 0 & 0 & 0 & 1 \\
0 & 0 & 0 & 0 & \frac{-k_{1}}{J_{1} \frac{r_{2}}{r_{1}}-J_{2}} & \frac{-b_{1}}{J_{1} \frac{r_{2}}{r_{1}} J_{2}} & \frac{k_{2}}{J_{1} \frac{r_{2}}{r_{1}}-J_{2}} & \frac{b_{2}}{J_{1} \frac{r_{2}}{r_{1}}-J_{2}}
\end{array}\right]+} \\
& +\left[\begin{array}{c}
0 \\
0 \\
0 \\
\frac{k_{w}}{m_{u s}} \\
0 \\
0 \\
0 \\
0
\end{array}\right] z_{r}
\end{aligned}
$$

\section{B. Linear Electromagnetic Suspension Generator}

The linear generator consists of two parts: primary part with three-phase winding placed in the slots of primary core, and secondary part with permanent magnets attached to the iron core which depicted as Figure 5. During the oscillation of the vehicle, the secondary part is moving with respect to the primary part. Due to the relative linear motion of primary winding and secondary permanent magnets, an AC voltage is induced in the coils. This voltage is then rectified by the 3-phase controlled converter and supplies a battery. The electrical model of electromagnetic shock absorber attached to vehicle is modeled as Figure 6.

The winding parameters depend on the voltage of the accumulator and on the damping force that the generator ought to perform. In order to transmit the power from the generator to the battery, the line emf $E$, induced in the winding, must be greater than the voltage of the accumulator $\mathrm{Va}$. The phase electromotive force is proportional to the linear speed $v$ :

$E_{\varnothing}=K_{E} v$

with generator constant :

$K_{E}=2 N_{c} B_{w} l_{t} p$

where:

$\mathrm{N}_{\mathrm{c}}$ : number of coil

$\mathrm{B}_{\mathrm{w}}$ : magnetic flux density.

$\mathrm{l}_{\mathrm{t}}$ : length of coil turn

$\mathrm{p}$ : number of pole

The generated electromotive force at steady state condition is:

$E=V_{s}+2\left(R_{a}+R_{s}\right) I$

Since damping force is

$F_{e m}=K I$ can be write in term of the speed, resistance and the voltage source as :

$F_{e m}=K\left(\frac{K_{v}-V_{s}}{2 R_{a}-R_{s}}\right)$

This is show that electromagnetic damper has viscous characteristic as well as hydraulic damper.

\section{RESULTS AND DISCUSSION}

In this section we give some simulation result and discussing energy regenartion and comfort enhancement due to both of electromagnetic shock compared to hydraulic shock absorber. Table 1 shows the vehicle and rotary electromagnetic damper simulation parameters. Bumpy input road signal as follow Equation 19:

$$
r(t)=\left\{\begin{array}{c}
\frac{a(1-\cos 8 \pi t)}{2}, 0.5<t<0.75 \\
0, \text { others }
\end{array}\right.
$$

Body bouncing and sprung mass acceleration are shown by Figure 7 and Figure 8 respectively. Figure 9 represent amount of power regenerated at frequency domain. And Table 2 shows parameters of linear electromagnetic damper. It will be simulated steady state and dynamic condition toward the parametes.

Steady state characteristic of linear electromagnetic shock absorber: Linear electromagnetic shock absorber has viscous characteristic as well a hydraulic shock absorber. Figure 10 show the damping characteristic when supply voltage: $0 \mathrm{~V}, 12 \mathrm{~V}$, and $24 \mathrm{~V}$.

Efficiency absorbtion is going to be fine when supply voltage $\mathrm{Vs}=24 \mathrm{~V}$ rather than $\mathrm{Vs}=12 \mathrm{~V}$. Figure 11 show relation between absorbtion energy effiecency and vertical velocity of unsprung mass with different supply voltage. Performance at dynamic condition: Linear generator model represented by Figure 12 and Equation 20.

$e=V_{s}+\left(2 R_{a}+R_{s}\right) i+L \frac{d i}{d t}$

For three phase generator, it should be:

$e_{A B}=K_{E}\left(\sin (\omega t)-\sin \left(\omega t-120^{\circ}\right)\right)$

$e_{B C}=K_{E}\left(\sin \left(\omega t-120^{\circ}\right)-\sin \left(\omega t-240^{\circ}\right)\right)$

$e_{C A}=K_{E}\left(\sin \left(\omega t-120^{\circ}\right)\right)$

Generator output at steady condition is shown by Figure 13. While vehicle through bumpy road as follow Equation 19, damping force and relative vertical speed of shock absorber are shown by Figure 14 and 15 respectively. Voltage and current generated by shock absorber is shown by Figure 16 and 17 respectively.

Figure 18 shows power generated by the shock absorber such it was cross product between current and voltage. Electromagnetic linear generator suspension absorbs more power than angular generator, because a little losses due to energy conversion. It shown by figure 16 which has 90 watt power regeneration in peak compared to angular generator that has $3.5 \times 10^{-7}$ Watt in peak.

The linear shock absorber more comfort than angular shock asorber. It can reduce oscilation shown by Figure 19 which the sistem has $1.2 \mathrm{sec}$ settling time while angular shock absorber has $3 \mathrm{sec}$. It is proper to get more energy when vehicle pass on unevenness road. Since the excitation of the suspension by the road can be considered as randon and Gaussian signals, the road input can be expressed As Equation 21: This generator can generate 64 Watt mean power with maximum bounce $0.03 \mathrm{~m}$.

$\dot{z}_{r}=-2 \pi f_{0} z_{r}+2 \pi \omega \sqrt{G_{0} v}$

where:

$\mathrm{f}_{0}$ : Lower limiting frequency

$\omega:$ zero mean white noise process

$\mathrm{G}_{0}$ : road uneven coefficient

$\mathrm{v}$ : vehicle speed

Body bounce and power regenerated are shown by Figure 20 and 21 respectively. 


\section{CONCLUSION}

Both of energy harvester increase comfot and vehicle handling than conventional suspension. Linear electromagnetic shock absorber harvests much of energy

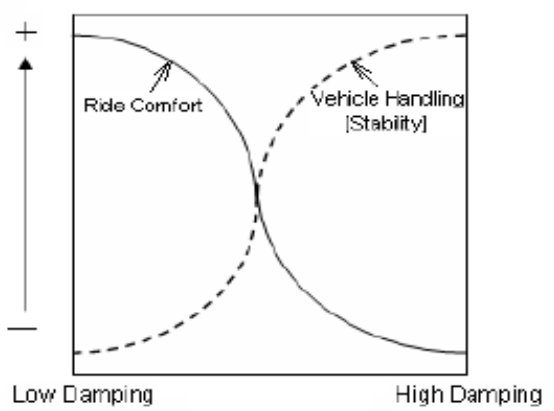

Figure 1. Comfort and handling performance
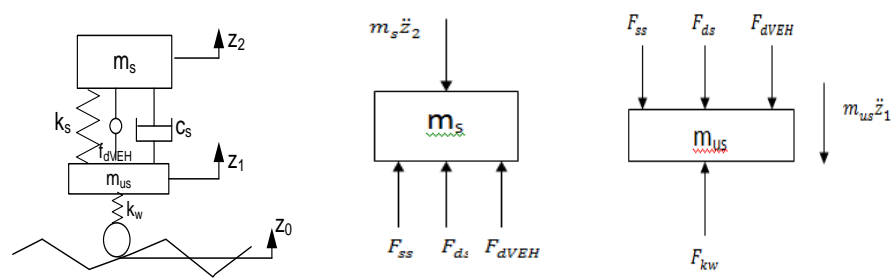

Figure 3. Free body diagram of dynamical system

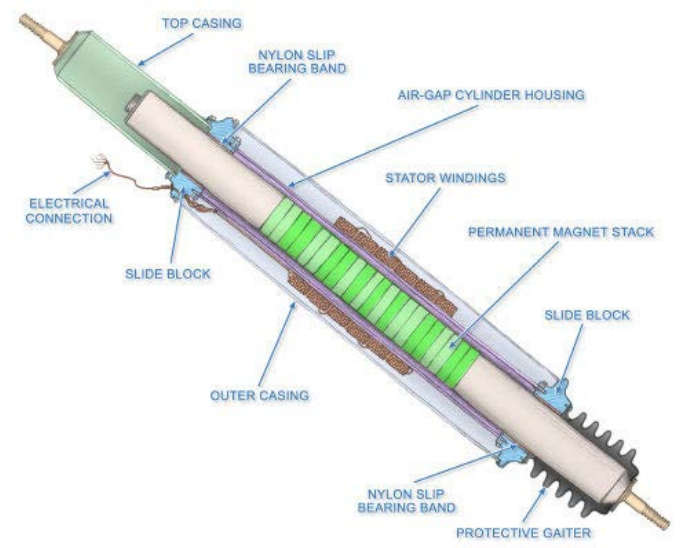

Figure 5. Linear electromagnetic suspension

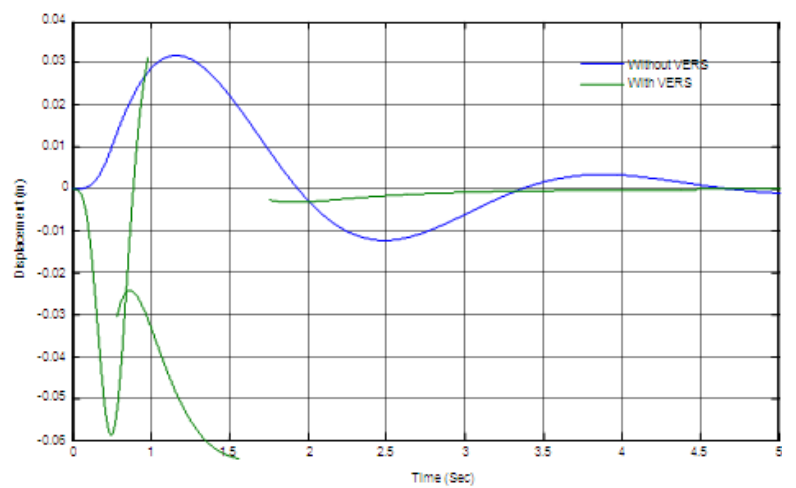

Figure 7. Body bouncing with and without rotary generator than angular harvester. Besides of this, it also makes vehicle more comfort and good in handling. But it is more complexity in construction.

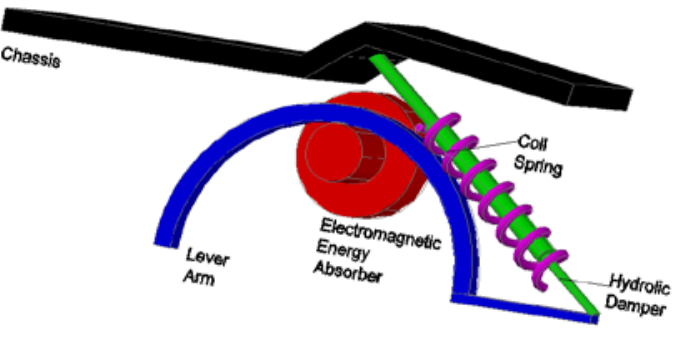

Figure 2. Rotary electromagnetic suspension

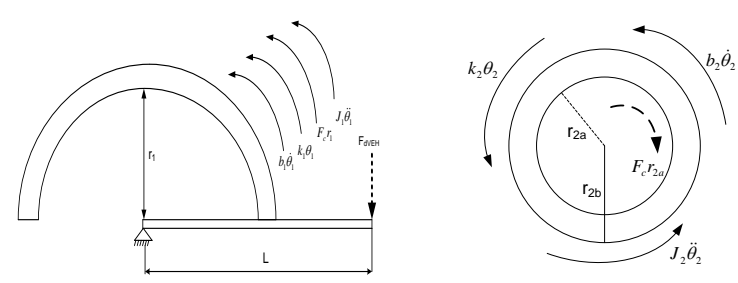

Figure 4. Free body diagram of rotary energy harvester

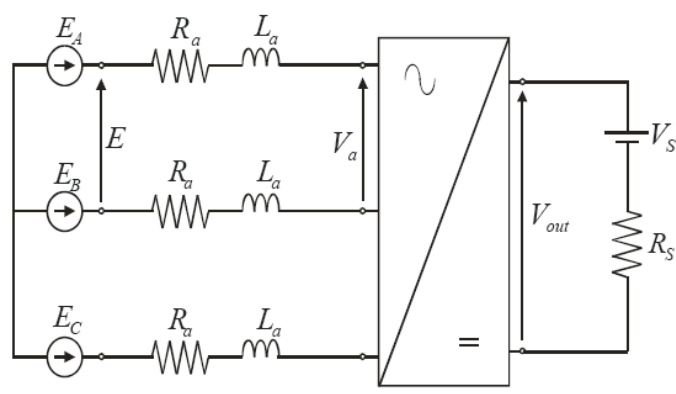

Figure 6. Electrical model of electromagnetic shock absorber

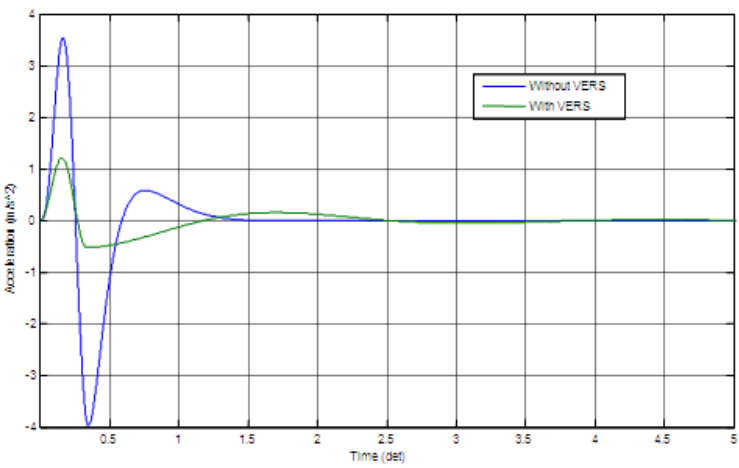

Figure 8. Body acceleration with and without rotary generator 


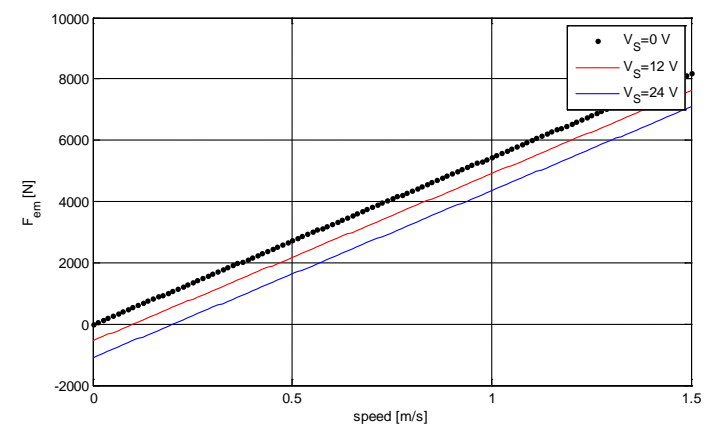

Figure 10. Damping characteristic of linear electromagnetic shock absorber

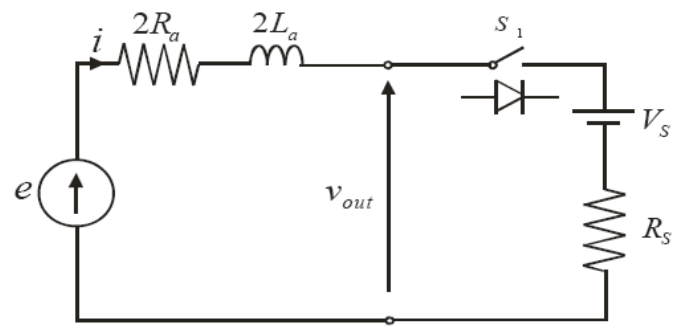

Figure 12. Generator model

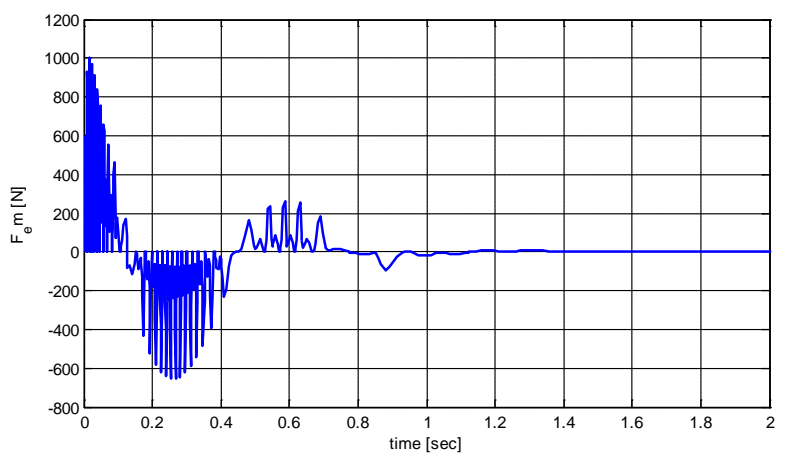

Figure 14. Shock absorber damping force

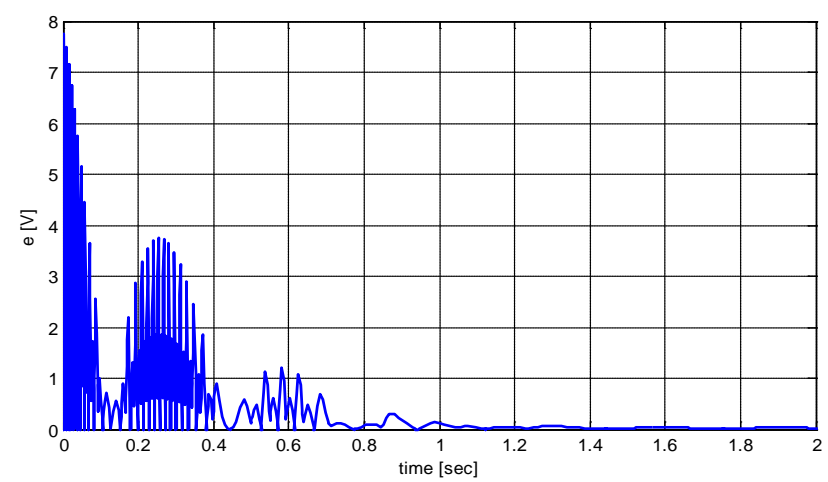

Figure 16. Voltage generated

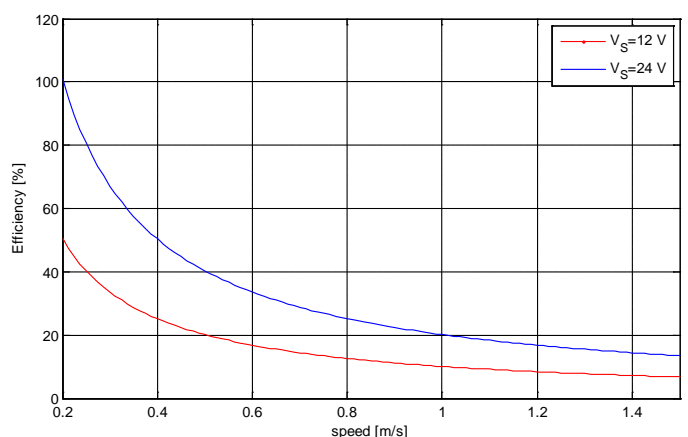

Figure 11. Relation between efficiency and unsprung mass vertical velocity with different voltage

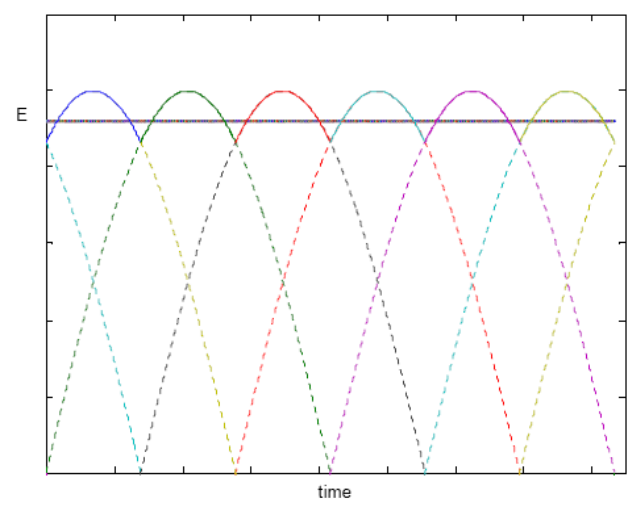

Figure 13. Linear generator output at steady condition

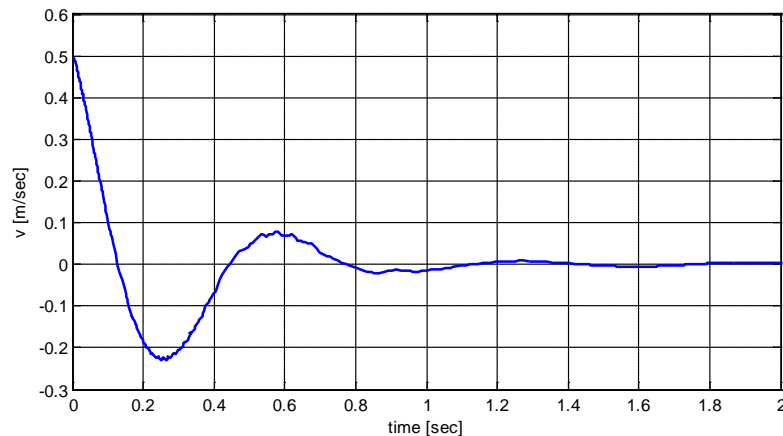

Figure 15. Relative vertical speed of shock absorber

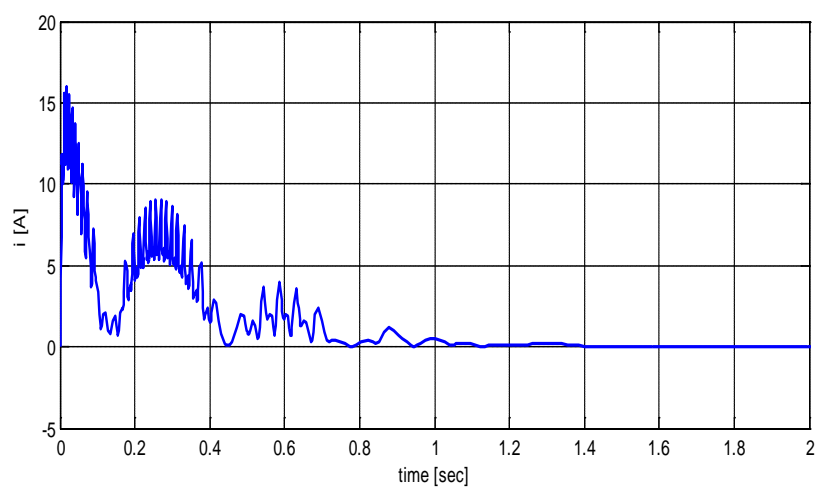

Figure 17. Current generated 


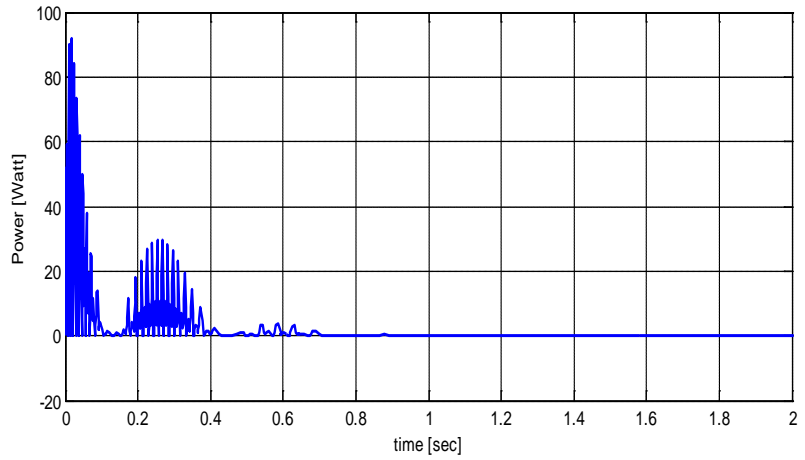

Figure 18. Power generated

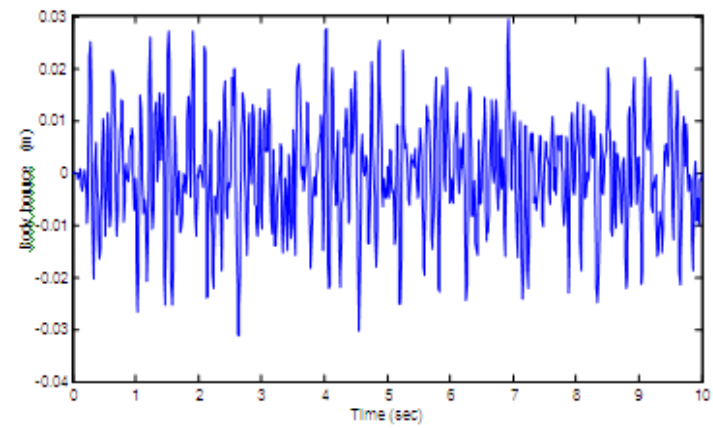

Figure 20. Body bounce with unnevenees road by using linear electromagnetic shock absorber

TABLE 1.

VeHicle AND Rotary ELECTROMAGNETIC DAMPER PARAMETERS

\begin{tabular}{|c|c|c|c|}
\hline Notation & Description & Value & Units \\
\hline $\mathrm{m}_{\mathrm{s}}, \mathrm{m}_{\mathrm{us}}$ & $\begin{array}{l}\text { Sprung mass and un- } \\
\text { sprung mass } \\
\text { respectively }\end{array}$ & 240,36 & $\mathrm{Kg}$ \\
\hline $\begin{array}{l}\mathrm{k}_{\mathrm{s}}, \mathrm{k}_{\mathrm{t}}, \\
\mathrm{k}_{1}, \mathrm{k}_{2}\end{array}$ & $\begin{array}{l}\text { Stiffness of suspension, } \\
\text { tire, gear and harvester } \\
\text { respectively }\end{array}$ & $\begin{array}{c}1600,16000 \\
32000,21000\end{array}$ & $\mathrm{~N} / \mathrm{m}$ \\
\hline $\mathrm{C}_{\mathrm{s}}, \mathrm{C}_{1}, \mathrm{C}_{2}$ & $\begin{array}{l}\text { Damping constant of } \\
\text { suspension, gear rack } \\
\text { and harvester } \\
\text { respectively }\end{array}$ & $\begin{array}{c}1290,2721 \\
1880\end{array}$ & $\mathrm{Ns} / \mathrm{m}$ \\
\hline $\mathrm{r}_{1}, \mathrm{r}_{2}, \mathrm{r}_{\mathrm{c}}$ & $\begin{array}{l}\text { Radius of gear rack, } \\
\text { harvester and magnetic } \\
\text { coil respectively }\end{array}$ & $0.1,0.05,0.07$ & $\mathrm{~m}$ \\
\hline $\mathrm{J}_{1}, \mathrm{~J}_{2}$ & $\begin{array}{l}\text { Inertia of gear rack and } \\
\text { harvester respectively }\end{array}$ & $0.074,0.046$ & $\mathrm{Kg} / \mathrm{m}^{2}$ \\
\hline $\mathrm{N}$ & $\begin{array}{c}\text { Number of } \\
\text { electromagnet coil }\end{array}$ & 25 & \\
\hline B & Magnetic flux densities & 1.17 & $\mathrm{~T}$ \\
\hline $\mathrm{l}$ & Length of coil & 500 & $\mathrm{~mm}$ \\
\hline
\end{tabular}

\section{REFERENCES}

[1] L. Zuo, B. Scully, J. Shestani and Y. Zhou, "Design and characterization of an electromagnetic energy harvester for vehicle suspensions "Smart Mater. Struct pp.1-10, IOP Publishing, UK. February.2010

[2] Z. Longxin and W. Xiaogang, "Structure and Performance Analysis of Regenerative Electromagnetic Shock Absorber", Journal of Networks, Vol. 5, pp.1467-1474, December.2010.

[3] S.P. Beeby, R.N. Torah, M.J. Tudor, P. Glynne-Jones,T. O’Donnell, C.R. Saha and S. Roy, "A micro electromagnetic generator for vibration energy harvesting", Journal Of Micromechanics And Microengineering pp.1257-1265, IOP Publishing , UK.2007

[4] D. Mammosser and E. Foltête M. "Collet Scavenging energy from a vibrating beam using an electromagnetic transducer", 12th IFToMM World Congress, Besançon (France), 2007.

[5] K. Nakano, Y. Suda, and S. Nakadai, "Self-powered active vibration control using a single electric actuator", Journal of Sound and Vibration pp 213-235.2007.

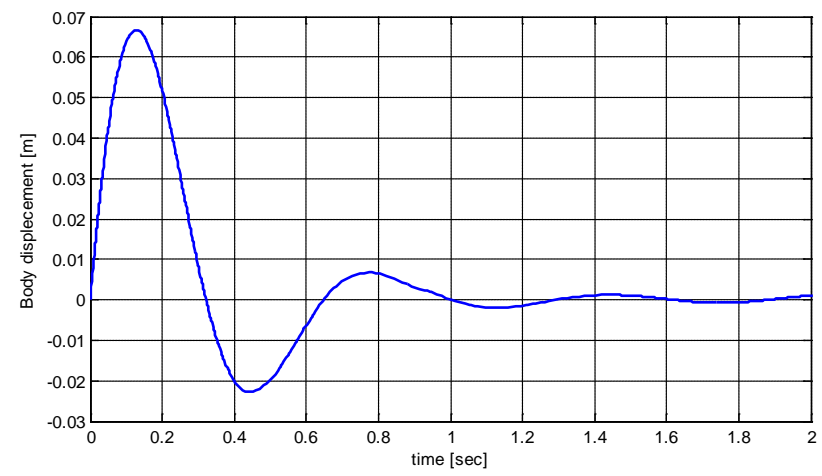

Figure 19. Body displacement

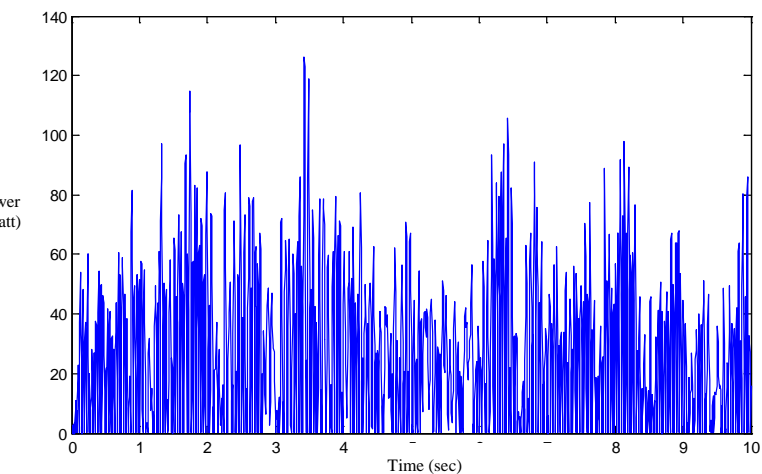

Figure 21. Power regenerated by linear electromagnetic shock absorber at unnevenees road

TABLE 2.

LinEAR ELECTROMAgNETIC SHOCK ARBSORBER PARAMETERS

\begin{tabular}{cccc}
\hline Notation & Description & Value & Units \\
\hline $\mathrm{V}_{\mathrm{s}}$ & Voltage Source & 12 & $\mathrm{~V}$ \\
$\mathrm{~K}_{\mathrm{E}}$ & Voltage damping constant & 72 & $\mathrm{~V} . \mathrm{s} / \mathrm{m}$ \\
$\mathrm{R}_{\mathrm{a}}$ & Phase resistance & 1.3 & $\Omega$ \\
$\mathrm{L}_{\mathrm{a}}$ & Phase Inductance & 6.5 & $\mathrm{mH}$ \\
$\mathrm{np}$ & Number of pole & 3 & poles \\
\hline
\end{tabular}

[6] A.A. Aldair, and W.J. Wang, "The Energy Regeneration of Electromagnetic Energy Saving Active Suspension In Full Vehicle With Neurofuzzy Controller", International Journal of Artificial Intelligence \& Applications. Vol.2, No.2, pp.32-43, April. 2011.

[7] A. Shirahatt, P.S.S. Prasad, P. Panzade, M.M. Kulkarni, "Optimal Design of Passenger Car Suspension for Ride and Road Holding", J. of the Braz. Soc. of Mech. Sci. \& Eng, Vol. XXX , pp 6776.2009. January.2008.

[8] B. Ebrahimi, "Development of Hybrid Electromagnetic Dampers for Vehicle Suspension Systems", Ph.D Thesis, Mechanical Engineering Dept, Univ. waterloo, Ontario, Canada, 2009

[9] ISO: 2631-1, 1997, "Mechanical vibration and shock - Evaluation of human exposure to whole-body vibration".

[10] A.I. Sultoni, I.N. Sutantra, A. S.Purnomo, H.L.Guntur, "Energy Harvester for Multi Purpose Vehicle Comfortabillity Enhancement Using Electromagnetic Damper Mechanism", $3^{\text {rd }}$ APTECS, International Seminar on Applied Technology, Science and Arts, Surabaya, 2011. 